\title{
Determined aphid-host plant relations from Eastern Black Sea regions of Turkey
}

\author{
Türkiye'nin Doğu Karadeniz Bölgesi'nden tespit edilen afit-konak bitki ilişkileri \\ Gazi GÖRÜR ${ }^{a^{*}} \odot$, Hayal AKYILDIRIM BEĞEN ${ }^{b} \odot$, Özhan ŞENOL ${ }^{a}{ }^{\circ}$ \\ a Department of Biotechnology, Faculty of Art and Science, Niğde Ömer Halisdemir University, Niğde, Turkey \\ ${ }^{\mathrm{b}}$ Health Services Vocational School, Artvin Coruh University, Artvin, 08000 Turkey
}

\section{Article Info}

(C)2018 Ali Nihat Gökyiğit Botanical

Garden Application and Research Center of Artvin Çoruh University.

*Corresponding author:

e-mail: ggorur@ohu.edu.tr

ORCID: 0000-0001-5713-418X

\section{Article history}

Received: April 12, 2019

Received in revised form: August 07, 2019

Accepted: August 07, 2019

Available online: August 09, 2019

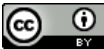

This is an Open Access article under the CC BY license (http://creativecommons.org/licenses /by/4.0/).

\section{Keywords:}

Aphid, Black Sea, fauna, plant, Turkey.

Anahtar kelimeler:

Afit, bitki, fauna, Karadeniz, Türkiye.

\begin{abstract}
Aphid-host plant relationship has fascinated scientist for a long time as they had some tight interactions. There is considerable amount of mountainous land area in Far Eastern Black Sea Region of Turkey which is almost $27 \%$ and about 165 aphid species have been determined. There has been no study conducted either to detect aphid fauna of region or aphid-host plant interaction up to last decades. Compared with determined aphid species diversity with floristic richness of region and each province, number of the aphid species recorded does not reflect real aphid composition of study area. According to proposed model related with aphid-host plant diversity around the world, both heavy rainfall and mix of higher vegetation biodiversity especially underbrush plant richness might explain unexpected lower aphid species diversity compared with higher plant diversity. Recent studies carried out clearly indicated that aphid-host plant relations should be studied in detail as these relations are become much more dynamic as a result of recent climatic changes.

öz

Kendi aralarında sıkı etkileşime sahip olan afit-konak bitki ilişkileri biliminsanlarını uzun süreden beri etkilemektedir. Türkiye'nin Doğu Karadeniz Bölgesi'nde kayda değer miktarda (\%27) dağlık arazi alanı vardır ve bu alandan yaklaşık 165 afit türü tespit edilmiştir. Bölgenin afit faunası veya afit-konak bitki ilişkilerini son yıllarda belirlemek amacıyla herhangi bir çalışma yapılmamıştır. Bölgenin floristik zenginliği ile belirlenen afit tür çeşitliliğini karşılaştırıldığında, kaydedilen afit türü sayısı çalışma alanının gerçek afit sayısını yansıtmamaktadır. Dünyadaki afit-bitki çeşitliliği ile ilgili tahmini modele göre, hem yoğun yağış hem de yüksek vejetasyonlardaki karışık biyoçeşitliliğe sahip olan, özellikle de bitkisel zenginliğe sahip ormanaltı alanlar gibi bölgeler ile karşılaştırıldı̆̆ında, afit tür çeşitliliği miktarının beklenenin altında bir sayıda olduğunu açıklayabilir. Son zamanlarda yapılan çalışmalarda, afit-konak bitki ilişkilerinin son iklim değişikliklerinin bir sonucu olarak çok daha dinamik hale gelmesi nedeniyle detaylı olarak çalışılması gerektiği açıkça göstermektedir.
\end{abstract}

Citation:

To cite this article: Görür G, Beğen HA, Şenol Ö (2019). Determined aphid-host plant relations from Eastern Black Sea regions of Turkey. Turk J Biod 2(2): 34-38.

\section{INTRODUCTION}

There are about $391.000,00$ plant species identified around the world and about 2.000 new plant species are discovered each year. Among 242 countries, Brazil has the highest number of plants species with about 60.000 records (Lewinsohn \& Prado, 2005). Turkey is a bridge between Asia and Europe, one of the largest countries in Europe, has the richest flora in Europe, has unique geographical features and a variety of climates. These characteristic properties of the Turkey resulted in both animal and plant diversity. Turkey is placed in the 22th order with about 12.000 defined plant species (Eminağaoğlu, 2015; Güner et al., 2012). While about 391.000 plant species have been identified so far, the known world fauna of aphids (Hemiptera: Aphidoidea) recently reached a total of 5100 species, placed in 510 currently accepted genera (Blackman \& Eastop, 2019; Favret, 2019) and it has been shown that about 300 plant families colonized by aphid species. Aphids are economically important pests of agriculture and forest crops. They suck phloem sap by mouthparts modified into 
stylets and due to their feeding mode they even accepted as plant parasites. These characteristic of the aphids let them to be studied in both biodiversity manner and aphid-host plant relations. The number of aphid species in Turkey aphid fauna reached about 570 species with recent records (Görür et al., 2018). Initial proposal offered by various aphid researchers group indicated parallel diversity between plant species and aphid diversity which is one of the important pest species. Despite this common approaches there is no real correlation between number of the plants species and number of the aphid species colonized on these plants due to various effects on aphidhost plant relations such as climate basically temperature and pour with rain, plant physiology, effectiveness of secondary metabolites, humidity (Dixon, 1998). In this context, there is an important question should be answered whether there is positive correlation between plant species diversity and aphid species diversity in Eastern Black Sea Region of Turkey? This area has the highest amount of precipitation and about $27 \%$ of the land is covered by mountain in Turkey. Despite these huge potential to analyze aphid-host plant relation in this region, there had been no study organized to determine aphid fauna of the study area up to 2009. Project carried out by Görür et al (2009) determined about 165 aphid species from Artvin, Trabzon and Rize provinces and these samples were collected on nearly 220 plant species. Detailed studies required to clarify existed aphid-host plant relations in study area and make future proposal for aphid-host plant relations in Turkey.

\section{MATERIAL AND METHOD}

Aphid sampling on naturally grown trees and herbaceous plants, agricultural crops, ornamental plants was started in 2007, more than 3500 sampling were conducted from study area and it has been actively continuing to follow current aphid-host plant relations. It has been shown that there were differences in total sampling among studied provinces related with their climate, floristic richness, variety in agricultural crops and landscape (Figure 1).

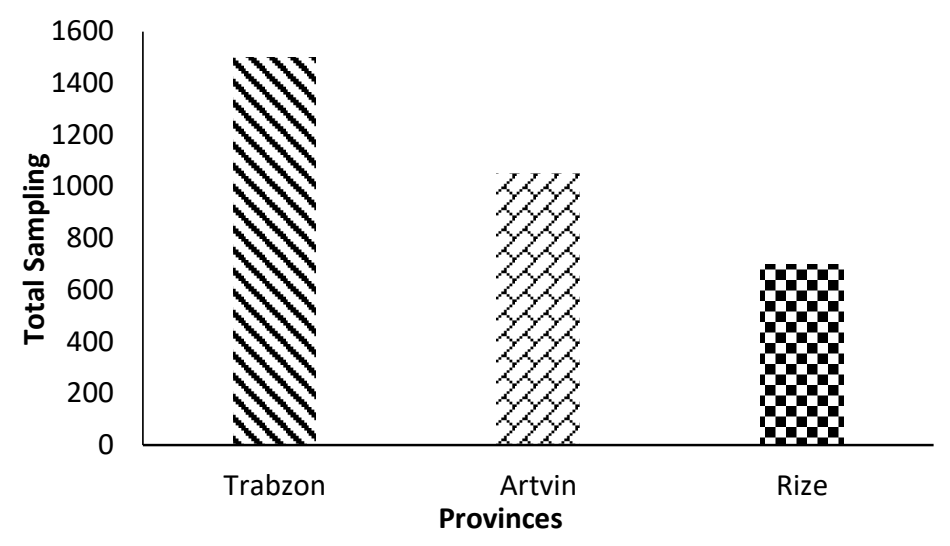

Figure 1. Total sampling in study area.

Samples were processed in a laboratory based on the methods offered by Martin (1983). Species were identified according to internationally accepted and followed identification keys and their taxonomic status checked in accordance with the recently evaluated sources and literatures (Blackman \& Eastop, 2006, 2019; Favret, 2019; Nieto Nafria, 2019). Host plants were identified according to current literatures and identification keys. Voucher samples stored at the Biotechnology Department of the Niğde Ömer Halisdemir University.

\section{RESULTS}

As a result of the evaluation of the aphid samples collected on various host plants that represent general characteristics of study area, 164 aphid species recorded from Artvin, Trabzon and Rize provinces on about 220 plant species. Among these identified species, 42 species and 5 genera were new records for Turkey aphid fauna and about 120 aphid species were new records for study area as there was no study carried out before conducted project. Overall contribution of the ended project to Turkey aphid fauna is about $10 \%$ new records. Further analyses were performed on obtained aphid sampling and collected host plants to the have foresight to aphidhost plant relationships. Detailed analyses showed that Trabzon has the highest number of aphid species and followed by Artvin and Rize provinces respectively (Figure 2). Of these determined species among 3 provinces, 32 species were recorded from all study areas, 20 species shared in both Artvin and Trabzon, 11 species are common in Trabzon and Rize and interestingly only 6 species shared between Artvin and Rize. 


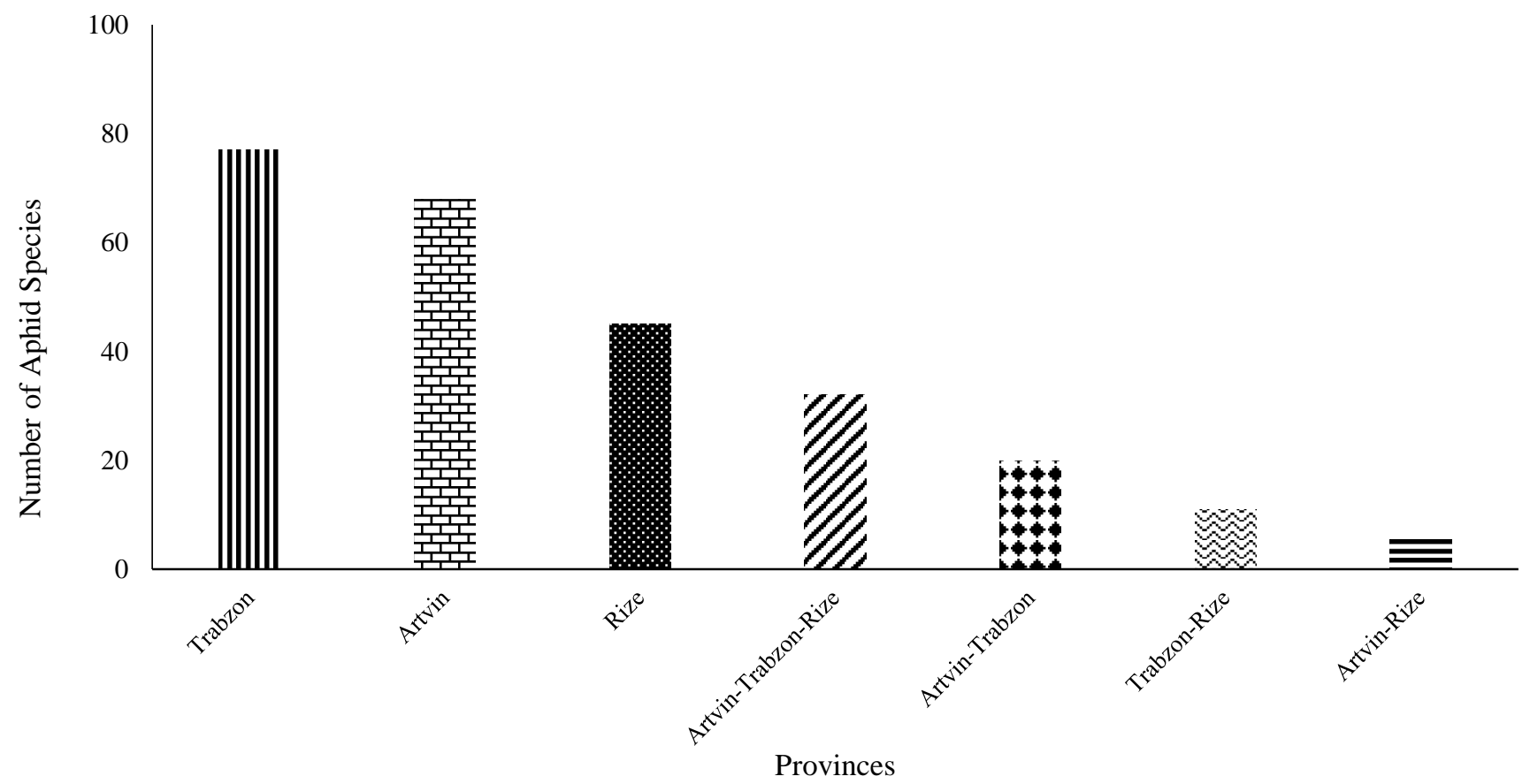

Figure 2. Number of the aphid species in study area per Province and shared between localities.

It has been thought that the differences in number of the aphid species recorded from 3 provinces are remarkable as they are located in same geographical area. These differences should be evaluated in consideration of ecological conditions of the study area (Table 1 ).

Table 1. Basic ecological features of study area, total plant species and determined aphid species

\begin{tabular}{|l|l|l|l|l|}
\hline Provinces & $\begin{array}{l}\text { Mean } \\
\text { Temperatures }\end{array}$ & Precipitation & $\begin{array}{l}\text { Number } \\
\text { of the } \\
\text { plant } \\
\text { species }\end{array}$ & $\begin{array}{l}\text { Number } \\
\text { of the } \\
\text { aphid } \\
\text { species }\end{array}$ \\
\hline Artvin & $11.8^{\circ} \mathrm{C}$ & 1168 & 2727 & 68 \\
\hline Rize & $14.3^{\circ} \mathrm{C}$ & 2298 & 1430 & 45 \\
\hline Trabzon & $14.4^{\circ} \mathrm{C}$ & 891 & 2100 & 77 \\
\hline
\end{tabular}

\section{DISCUSSION}

The relationship between host plant diversity and aphid diversity have fascinated scientist for a long time. It has been thought that under the normal conditions there should be positive correlation between aphid species diversity and plant species diversity in any particular locality as aphid fed on directly plant phloem sap, and they cannot survive for a long time if they do not manage to colonize any host plant. Despite these common approaches it has been shown that the numbers of aphid species that have colonized various families of plant is not clearly correlated. Clear evidences have supported these unparalleled relations between aphid diversity and plant species diversity. For example, the Compositae has the highest number of aphid species fed on while it is the third most diverse plant group. In contrast to Compositae family, Coniferae family is ranked in 58th plant richness and in the second place in hosting number of aphid species (Dixon, 1998). These unparalleled pattern also has been recognizable at the geographical level or country level. Brazil has the highest number of plant species around the world but only 87 aphid species listed for Brazil aphid fauna (Lazzarotto \& Lazzari, 2005). Lower aphid species diversity might be related with way of their reproduction. Despite there is no reached consensus, as a result of the climatic conditions of the tropical regions particularly temperature sexual phase of the aphid reproduction inhibited and these led to reduction species diversity (Dixon, 1998; Blackman \& Eastop, 2019). Following these general context, similar cases were reported in Turkey. Overall evaluation of Turkey floristic richness and number of the aphid species, there are 
about 12.000 plant species have been identified and approximately 570 aphid species determined (Eminağaoğlu, 2015; Güner et al., 2012; Gorur et al., 2012; Şenol et al., 2017; Görür et al., 2018). About 164 aphid species recorded from Artvin, Rize and Trabzon Provinces which are located Far Eastern Part of the Black Sea Region. Study area is the wettest locality of Turkey and has almost richest flora with about 7000 plant species. Analyses of finding of the study area in terms of aphid species diversity and plant species diversity, there are similar pattern with existed relations. To support this idea, about 90 aphid species recorded from Niğde which is located in Inner Anatolia where step vegetation is dominant and one of the driest area in Turkey. If there is a close relationship between aphid species and plant species diversity, we would record many more aphid species from study area. Basic question should be answered here in this particular conditions how do we explain lower aphid species determination although there plenty of plant species richness? When trying to find out answer of this question, findings might both be considered together and by each Province. The lowest aphid species recorded from Rize Provinces where the average highest precipitation recorded. The highest number of the aphid species recorded from Trabzon Province and the lowest rainfall. It has been considered that rainfall might cause differences in determined aphid species among studied provinces and also from the other regions of Turkey as there are some studies indicated how negatively strong rainfall effect aphid biodiversity and seasonal variability (Kaakeh \& Dutcher, 1993). In addition to strong rainfall in study area during sampling period and average values compared with other regions of Turkey, it has been considered that there are a lot of underbrush plant species and most of them do not get enough sunshine. Lower sunshine might influence quality of photosynthesis product and therefore aphid species should not prefer this underbrush. Dixon et al. (1987) and Mackenzie et al. (1994) and proposed a model that regional species diversity of aphid increases at some intermediate plant species richness while declined in areas of high vegetation complexity. Lower aphid species recorded from Far Eastern Black Sea Region where higher floristic richness might be explained with this existed model (Eminağaoğlu, 2015). Even findings are matching with existed literatures, there should be much more studies conducted to follow aphid-host plant relationships as this relationship become highly dynamic as a result of the current climatic changes. Recent global climatic changes result in many species to be invasive including both aphid species and plant species and there has been considerable number of invasive aphid species recorded from Turkey (Akyıldırım et al., 2013). It has been considered that higher potential of invasive and exotic species in near future in Turkey might break down determined aphid-host plant relations.

\section{Acknowledgments}

Authors thank to TUBITAK (Project number: 107T450)

for partial support for this study.

\section{REFERENCES}

Akyıldırım H, Şenol Ö, Görür G, Demirtaş E (2013). Evaluation of the zoogeographical contents of Turkey aphid (Hemiptera: Aphidoidae) fauna and invasive component. Biyoloji Bilimleri Araştırma Dergisi $6(1): 44-48$

Blackman RL, Eastop VF (2006). Aphids on the World's Herbaceous Plants and Shrubs. Vol:2 John Wiley \& Sons, Inc, 1460 pp.

Blackman RL, Eastop VF (2019). Aphids of the world's plants. An online identification and information guide. http://www.aphidsonworldsplants.info. Downloaded on 28 February 2019.

Dixon AFG (1998). Aphid Ecology. London: Chapman \& Hall 2-6 Boundary Row.

Dixon AFG, Kindlmann P, Leps J, Holman J (1987). Why are there so few species of aphids, especially in tropics. The University of Chicago Press Journal 129(4): 580-592.

Eminağaoğlu Ö (Ed.) 2015. Artvin'in Doğal Bitkileri. İstanbul: Promat, $456 \mathrm{p}$.

Favret C (2019). Aphid Species File 5.0/5.0. http://aphid.speciesfile.org. Downloaded on 22 February 2019.

Görür G, Zeybekoğlu Ü, Akyürek B, Işık M, Akyıldırım H (2009a). Trabzon, Rize ve Artvin illerinin afit (Homoptera: Aphididae) faunasının belirlenmesi, Proje No: Tubitak 107T450, 205p.

Gorur G, Akyildirim H, Olcabey G, Akyurek B (2012). The Aphid Fauna of Turkey: An Updated Checklist. Archives of Biological Science Belgrade 64(2): 675-692.

Görür G, Şenol Ö, Parmaksız D (2018). Adıyaman Malatya ve Şanlıurfa Illeri Afit Hemiptera Aphidoidea Faunasının Belirlenmesi. Proje No: Tubitak 115Z325, 263p.

Güner A, Aslan S, Ekim T, Vural M, Babaç MT (2012). Türkiye Bitkileri Listesi (Damarlı Bitkiler). İstanbul, Turkey: Flora Araştırmaları Derneği ve Nezahat Gökyiğit Botanik Bahçesi Yayını.

Kaakeh W, Dutcher JD (1993). Effect of rainfall on populations of aphids (Homoptera: Aphididae) on pecan. Journal of Entomological Science 28: 283-286. 
Lewinsohn TM, Prado PI (2005). How many species are there in Brazil?. Conservation Biology 19(3): 619-623.

Lazzarotto CM, Lazzari SMN (2005). Analise faunistica de afideos (Hemiptera: Aphididae) na Serra do Mar, Parana, Brazil. Revista Brasileira de Entomologia 49(2): 270-274.

Mackenzie A, Dixon AFG, Kindlmann P (1994). The relationship between the regional number of aphid species and plant species diversity. European Journal of Entomology 91: 135-138.
Martin JH (1983). The identification of common aphid pests of tropical agriculture. Tropical Pest Management 29: 395-411.

Nieto Nafria J (2019). Fauna Europaea. Available from: www.faunaeur.org. Downloaded on 24 January 2017.

Şenol Ö, Akyıldırım H, Görür G (2017). Recent findings on aphid fauna from east and south eastern parts of Turkey. Biological Diversity and Conservation 10(3): 76-78. 